\title{
ANALISIS KINERJA KELEMBAGAAN TATA NIAGA PASAK BUMI (Eurycoma longifolia Jack) YANG BERKELANJUTAN DI KABUPATEN KUBU RAYA DAN KOTA PONTIANAK, KALIMANTAN BARAT (Perfomance Analysis of Sustainable Trading Institution of Pasak Bumi (Eurycoma longifolia Jack) in Kubu Raya Regency and Pontianak City, West Kalimantan Province)
}

\author{
SM. Kartikawati ${ }^{1}$, Ervizal A.M. Zuhud ${ }^{2}$, Agus Hikmat ${ }^{2} \&$ Hariadi Kartodihardjo ${ }^{3}$ \\ ${ }^{1}$ Fakultas Kehutanan Universitas Tanjung Pura \\ Jl. A. Yani, Pontianak, Indonesia \\ e-mail : kartikawt@gmail.com \\ ${ }^{2}$ Departemen Konservasi Sumber Daya Hutan dan Ekowisata, Fakultas Kehutanan IPB, \\ Jl. Lingkar Akademik Kampus IPB Darmaga, Bogor, Indonesia \\ ${ }^{3}$ Departemen Manajemen Hutan, Fakultas Kehutanan IPB, \\ Jl. Lingkar Akademik Kampus IPB Darmaga, Bogor, Indonesia \\ Diterima 25 Februari 2014, direvisi 18 Maret 2014, disetujui 28 April 2014
}

\begin{abstract}
Pasak bumi (Eurycoma longifolia Jack) is one of the main non forest products actively traded in West Kalimantan. The marketing of pasak bumi presented specific characteristics directly related to the natural environment of pasak bumi. The strong mutual dependency between pasak bumi collectors and traders is central to understanding the marketing of pasak bumi. The main objective of this research is to assess the overall performance of the pasak. bumi trading. More specific goals are: (1) to analyze the determining factors of the trading chain, and (2) to analyze the interrelation between marketing characteristics and pasak. bumi collectors' and traders' behaviours. The research was carried out in Kubu Raya and Pontianak City, West Kalimantan Province. Primary and secondary data were collected by observation and in-dept interview and analyzed using an institutional analisis development framework. The result showed that institutionalpattern of the pasak bumi chain is a typicalpatron-client system. Low accessibility, asymmetric information, limitation on capital and high value of pasak bumi are all factors directly affecting the marketing institution. Stakeholder that obtained largest margin in trading system and profit margin is trader in the city.
\end{abstract}

Keywords: Eurycoma longifolia Jack (pasak bumi), institutional trading, patron-client.

\begin{abstract}
ABSTRAK
Pasak bumi (Eurycoma longifolia Jack.) merupakan salah satu hasil hutan bukan kayu yang aktif diperdagangkan di Kalimantan Barat. Bentuk kelembagaan tata niaga pasak bumi ini mempunyai karakteristik tersendiri sesuai dengan kondisi alam dimana pasak bumi tersebut diusahakan. Adanya hubungan saling ketergantungan antara pemungut dan pedagang perantara melahirkan pemahaman tentang kelembagaan tata niaga pasak bumi. Tujuan utama dari penelitian ini adalah menganalisis bentuk kelembagaan tata niaga pasak bumi. Tujuan khusus penelitian ini adalah : (1) menganalisis faktor-faktor yang mempengaruhi kelembagaan tata niaga pasak bumi, dan (2) menganalisis keterkaitan karakteristik kelembagaan tata niaga pasak bumi dengan perilaku pemungut dan pedagang pasak bumi. Penelitian dilaksanakan di Kabupaten Kubu Raya dan Kota Pontianak, Provinsi Kalimantan Barat. Pengumpulan data primer dan sekunder dilakukan dengan observasi dan wawancara mendalam. Analisis data menggunakan kerangka analisis pengembangan institusi. Hasil penelitian menunjukkan bahwa bentuk kelembagaan tata niaga pasak bumi adalah patron-klien. Rendahnya aksesibilitas, informasi pasar yang tidak seimbang, keterbatasan modal dan tingginya nilai pasak bumi merupakan faktor-faktor yang menentukan terbentuknya kelembagaan tata niaga. Besarnya margin keuntungan tiap pelaku tidak merata, hasil analisis menunjukkan margin keuntungan terbesar adalah pedagang di kota.
\end{abstract}

Kata kunci: Eurycoma longifolia Jack (pasak bumi), kelembagaan tata niaga, patron- klien

Analisis Kinerja Kelembagaan Tataniaga Pasak Bumi (Eurycoma longifolia Jack) yang Berkelanjutan di ..... (SM. Kartikawati et al.) 


\section{PENDAHULUAN}

Kinerja kelembagaan tata niaga merupakan hasil akhir dari suatu kegiatan tata niaga yang mencerminkan seberapa manfaat atau kerugian yang diterima atau ditanggung oleh masing-masing pelaku tata niaga. Kelembagaan menurut Schmid dalam Pakpahan (1989) dicirikan oleh tiga komponen utama, yaitu batas yuridiksi, hak atas properti dan aturan representasi. Batas yuridiksi menentukan siapa dan apa yang tercakup dalam suatu kelembagaan, terkandung makna bahwa batas yuridiksi berperan dalam mengatur alokasi sumberdaya. Hak atas properti mengandung pengertian hak dan kewajiban yang didefinisikan atau diatur oleh hukum, adat dan tradisi atau konsensus yang mengatur hubungan antara anggota masyarakat dalam hal kepentingannya terhadap sumberdaya. Aturan representasi mengatur permasalahan siapa yang berhak berpartisipasi dalam proses pengambilan keputusan mengenai suatu alokasi sumberdaya.

Secara historis tataniaga pasak bumi merupakan interaksi di antara pelaku-pelaku tataniaga mulai dari proses hasil pemungutan pasak bumi yang dilakukan oleh pemungut, kemudian pedagang perantara sebagai penghubung komoditi dengan pedagang dan konsumen akhir. Pasak bumi merupakan salah satu hasil hutan bukan kayu yang aktif diperdagangkan di Kalimantan Barat, namun demikian kinerja kelembagaan tataniaga pasak bumi saat ini belum efektif. Permasalahan pengelolaan dan pemanfaatan sumberdaya hutan selama ini selalu muncul bersamaan antara nilai ekonomi dan nilai ekologis. Secara ekonomi, pemanfaatan hasil hutan berkaitan dengan nilai keuntungan ekonomi namun di sisi lain akan menimbulkan dampak penurunan kualitas hutan dan lingkungannya.

Secara ekologi pasak bumi merupakan sejenis pohon yang terdapat di hutan tropis, terutama di Indonesia banyak terdapat di Kalimantan. Habitat pasak bumi banyak dijumpai di punggungpunggung bukit dengan kondisi lahan yang miring hingga pada ketinggian $700 \mathrm{~m}$ dpl dengan sifat penyebaran menyebar berkelompok (Heyne, 1987; Nuryamin, 2000; Julisasi, 1992). Kondisi populasi pasak bumi saat ini sudah dikategorikan sebagai tumbuhan langka dengan status terkikis (Rifai, 1992). Bahkan di Malaysia sejak tahun 2001 menetapkan status pasak bumi sebagai tumbuhan yang dilindungi.
Pasak bumi merupakan tumbuhan obat yang seluruh bagian tanaman dapat dimanfaatkan (akar, batang, kulit akar dan daun), namun umumnya yang dimanfaatkan adalah bagian akar. Beberapa studi secara farmakologis pasak bumi telah dilakukan terbukti memiliki senyawa anti kanker (Tee at al., 2007; Nurhanan et al., 2005), anti bakteri (Farouk dan Benafri, 2007), pengobatan osteoporosis laki-laki (Effendi et al., 2012), sitotoksik (Kuo at al., 2004; Kuo at al., 2003), aprodisiak (Ang at al., 2004; Ang at al., 2003), anti leukemia, dan prospektif untuk anti HIV (Sinder et al. 2005), antimalaria, dan disentri (Chan et al. 2005; Suresh at al., 2009).

Manfaat yang beragam tersebut menyebabkan permintaan pasak bumi sebagai bahan baku obat tinggi, sehingga mendorong eksploitasi di hutan alam meningkat. Selama ini kebutuhan pasak bumi hanya mengandalkan dari pemungutan pasak bumi liar dari hutan, bukan dari hasil budidaya dengan cara mencabut akarnya. Pemanenan dengan cara destruktif seperti mencabut pada bagian akar merupakan faktor krusial yang harus diperhatikan untuk kelestarian tumbuhan (Kala et al., 2004; Farooquee et al., 2004; Ghimire et al., 2005).

Masalah yang dihadapi dalam kelembagaan tataniaga pasak bumi di Kabupaten Kubu Raya dan Kota Pontianak saat ini belum efektif untuk mengontrol produksi pasak bumi yang berkelanjutan karena secara regulasi tataniaga pasak bumi belum diatur dan belum terdokumentasikan. Karakteristik lokasi pemungutan pasak bumi yang jauh terpencil mempunyai keterbatasan akses transportasi maupun akses informasi pasar. Hal ini menye-babkan keberadaan pedagang perantara menjadi penting dalam menghubungkan masyarakat dengan pasar. Proses transaksi ini selanjutnya melahir-kan hubungan ketergantungan antar kedua belah pihak. Karena keterbatasan akses tersebut, umumnya posisi tawar pemungut menjadi rendah dalam proses transaksi sehingga tidak memberikan margin pemasaran yang besar pada pemungut. Untuk itu penelitian mengenai análisis kinerja tataniaga pasak bumi perlu dilakukan dan pentingnya faktor kelembagaan dalam menentukan kinerja tata niaga tersebut, serta memahami keterkaitan karakteristik kelembagaan tataniaga pasak bumi dengan perilaku pemungut dan pedagang sehingga bisa memberikan insentif untuk menjaga kelestarian pasak bumi. 


\section{METODE PENELITIAN}

Penelitian ini dilaksanakan pada bulan Oktober 2012 sampai bulan Januari 2013 di Kabupaten Kubu Raya dan Kota Pontianak, Provinsi Kalimantan Barat. Lokasi penelitian mengikuti penelusuran jalur distribusi tataniaga pasak bumi.

Metode pengumpulan data dan analisis data secara rinci dapat dilihat pada Tabel 1 dan ber- dasarkan karakteristik kelembagaan yang terbentuk selanjutnya dilakukan analsis kinerja kelembagaan tataniaga pasak bumi dengan menggunakan kerangka analisis pengembangan institusi melalui penelusuran faktor eksogen (kondisi fisik/ material, atribut komunitas dan aturan main yang berlaku) yang mempengaruhi situasi aksi dan aktor dalam pengelolaan pemanfaatan pasak bumi seperti disajikan pada Gambar 1.

Tabel 1 Teknik pengumpulan data menurut tujuan penelitian

Table 1. Techniques of data collecting based on the research objectives

\begin{tabular}{|c|c|c|c|c|c|}
\hline $\begin{array}{l}\text { Tujuan } \\
\text { Penelitian } \\
\text { (Objective) }\end{array}$ & $\begin{array}{l}\text { Rujukan Teori } \\
\text { (Theory referred) }\end{array}$ & $\begin{array}{l}\text { Variabel yang Diukur } \\
\text { (Measured variable) }\end{array}$ & $\begin{array}{c}\text { Teknik } \\
\text { Pengumpulan } \\
\text { data } \\
\text { (Data collecting } \\
\text { technique) }\end{array}$ & $\begin{array}{l}\text { Analisis Data } \\
\text { (Data analysis) }\end{array}$ & $\begin{array}{c}\text { Output yang } \\
\text { Diharapkan } \\
\text { (Expected output) }\end{array}$ \\
\hline $\begin{array}{l}\text { Mengkaji } \\
\text { karakteristik } \\
\text { tataniaga pasak } \\
\text { bumi }\end{array}$ & $\begin{array}{l}\text { Kerangka } \\
\text { Analisis } \\
\text { Kelembagaan } \\
\text { IAD (Institutional } \\
\text { Analysis and } \\
\text { Development } \\
\text { Framework) } \\
\text { (Ostrom, 2005) }\end{array}$ & $\begin{array}{l}\text { - Karakteristik } \\
\text { sumberdaya alam } \\
\text { - Atribut komunitas } \\
\text { - Sistem Pengusahaan } \\
\text { - Aturan/kebijakan }\end{array}$ & $\begin{array}{l}\text { Observasi, } \\
\text { snowball sampling } \\
\text { Wawancara } \\
\text { mendalam } \\
\text { penelusuran } \\
\text { pustaka }\end{array}$ & $\begin{array}{l}\text { - Deskriptif } \\
\text { - Kualitatif }\end{array}$ & $\begin{array}{l}\text { Mengetahui } \\
\text { pola } \\
\text { kelembagaan } \\
\text { tataniaga pasak } \\
\text { bumi }\end{array}$ \\
\hline $\begin{array}{l}\text { Menganalisis } \\
\text { kinerja } \\
\text { kelembagaan } \\
\text { tataniaga pasak } \\
\text { bumi }\end{array}$ & & $\begin{array}{l}\text { Struktur } \\
\text { - Jumlah penjual dan } \\
\text { pembeli } \\
\text { - Frekuensi transaksi } \\
\text { - Sistem } \\
\text { kelembagaan } \\
\text { tataniaga } \\
\text { - Aturan/ norma } \\
\text { Perilaku } \\
\text { - Penetapan harga } \\
\text { - Individual } \\
\text { / berkelompok } \\
\text { - Terikat modal/ } \\
\text { tidak terikat modal }\end{array}$ & $\begin{array}{l}\text { Wawancara } \\
\text { mendalam } \\
\text { observasi }\end{array}$ & $\begin{array}{l}\text { - Margin share } \\
\text { - Farmer's } \\
\text { share } \\
\text { - Return on } \\
\text { investment } \\
\text { - Deskriptif } \\
\text { - Kualitatif }\end{array}$ & $\begin{array}{l}\text { Mengetahui } \\
\text { kinerja } \\
\text { kelembagaan } \\
\text { tataniaga pasak } \\
\text { bumi }\end{array}$ \\
\hline
\end{tabular}




\begin{tabular}{|c|c|c|}
\hline FAKTOR EKSOGEN & ARENA AKSI & \\
\hline $\begin{array}{l}\text { Kondisi Fisik/Ekologi } \\
\text { 1. Karakteristik sumberdaya } \\
\text { 2. Karakteristik sifat pasak bumi }\end{array}$ & $\begin{array}{c}\text { Situasi Aksi } \\
\text { Pemanfaatan } \\
\text { pasak bumi }\end{array}$ & $\begin{array}{c}\text { Kinerja Lembaga } \\
\text { Tataniaga Pasak bumi }\end{array}$ \\
\hline $\begin{array}{l}\text { Atribut Komunitas } \\
\text { 1. Mata Pencaharian } \\
\text { 2. Skill teknik pemungutan } \\
\text { pasak bumi } \\
\text { 3. Pengetahuan tentang } \\
\text { tanaman pasak bumi } \\
\text { 4. Jaringan kerja } \\
\text { 5. Kekuatan informasi dan } \\
\text { modal }\end{array}$ & $\begin{array}{l}\text { 2. Waktu : frekuensi } \\
\text { pemungutan / } \\
\text { transaksi } \\
\text { 3. Pola interaksi } \\
\text { 4. Proses penetapan } \\
\text { harga } \\
\text { 5. Margin share } \\
\text { 6. Farmer's share } \\
\text { 7. Biaya transaksi }\end{array}$ & \begin{tabular}{l}
\multicolumn{1}{c}{ Outcomes } \\
1. Pemanfaatan pasak \\
bumi yang \\
berkelanjutan \\
2. Margin share yg \\
seimbang \\
3. Biaya transaksi minimal \\
(efisien)
\end{tabular} \\
\hline $\begin{array}{l}\text { Rules in Uses } \\
\text { Aturan/kebijakan } \\
\text { 1. Aturan formal } \\
\text { 2. Norma/aturan adat }\end{array}$ & $\begin{array}{l}\quad \text { Pelaku } \\
\text { 1. Pemungut } \\
\text { 2. Pengumpul } \\
\text { 3. Tengkulak } \\
\text { 4. } \text { Pedagang }\end{array}$ & \\
\hline
\end{tabular}

Gambar 1. Kerangka penelitian Analisis Kinerja Kelembagaan Tataniaga Pasak Bumi (Eurycoma longifolia Jack) yang berkelanjutan (Studi Kasus di Kalimantan Barat) (Modifikasi dari Ostrom 2005).

Figure 1. Performance analysis of institutional research framen work of sustainable Pasak bumi distribution in Kubu Raya Regency and Pontianak. City, West kalimantan Province.

\section{HASIL DAN PEMBAHASAN}

\section{A. Karakteristik Sumberdaya}

Berdasarkan rejim hak kepemilikan (Bromley, 1992) kawasan Gunung Ambawang secara dejure merupakan state property dengan status hutan lindung (HL) sesuai surat ketetapan No 121/kptsII/2003 seluas 3.370 Ha. Secara legalitas pemanfaatan sumber daya hutan di hutan lindung diatur dalam Undang-undang No. 41 tahun 1999 tentang Kehutanan, Peraturan Pemerintah No. 6 tahun 2007 tentang Tata Hutan dan Penyusunan Rencana Pengelolaan Hutan serta Pemanfaatan Hutan, dan Peraturan Pemerintah No. 38 tahun 2007 tentang Pembagian Urusan Pemerintahan antara Pusat dan Daerah. Berdasarkan perauturanperaturan tersebut secara regulasi pemanfaatan pasak bumi melekat bundle of right berupa hak dimanfaatkan (right of withdrawal) dan hak dapat diakses (right of access) dengan surat izin pemungutan hasil hutan bukan kayu (IPHHBK) yang diberikan oleh pemerintah kabupaten/kota.
Secara defacto kawasan Gunung Ambawang merupakan common pool resources (CPRs), sehingga penggunaannya open access (Ostrom, 2003). Kondisi ini menyebabkan setiap individu mempunyai insentif sebagai free rider untuk ikut memanfaatkan tanpa ikut berkontribusi terhadap pengelolaan pasak bumi. Karakteristik CPRs pasak bumi ini terjadi karena sebagian bersifat sebagai barang publik (public goods) dan sebagian bersifat barang privat (private goods). Karakteristik public goods ini menimbulkan terjadinya free rider dan penggunaan berlebihan (overuse) (Ostrom dan Hess, 2007). Kartodihardjo (1998) menyatakan bahwa, rendahnya strata hak akan menyebabkan pemilik hak tidak mempunyai inovasi untuk melakukan pengelolaan sumber daya hutan secara berkelanjutan. Kepastian kepemilikan atas sesuatu yang langka sangat penting untuk dapat berlangsungnya proses transaksi dalam ekonomi pasar, sehingga semakin tinggi kepastian tersebut, biaya transaksinya semakin rendah. Berdasarkan pengamatan free rider pemungut pasak bumi yang dilakukan oleh masyarakat sekitar gunung 
Ambawang ini terjadi karena adanya akses menuju lokasi pasak bumi dan adanya jaringan pemasaran. Hal ini terlihat adanya interaksi antara pemungut, pedagang perantara dan pedagang di kota berupa dengan terbentuknya hubungan patron klien. Situasi ini lebih dikendalikan oleh web of power (Peluso dan Ribot, 2003), dimana adanya pola interaksi patron klien akses kekuasaan lebih berperan daripada klaim dalam kepemilikan.

\section{B. Atribut Komunitas}

Karakteristik komunitas yang mempengaruhi arena aksi dalam kelembagaan tata niaga pasak bumi dari masing-masing pelaku berbeda. Berdasarkan hasil pengamatan dan wawancara dengan pemungut, atribut komunitas yang mempengaruhi pemungut melakukan kegiatan pemungutan pasak bumi adalah adanya pemahaman bahwa pasak bumi merupakan tanaman yang bisa diakses untuk dipungut dan dijual; kegiatan pemungutan pasak bumi sebagai alternatif mata pencaharian; dan berdasarkan pengamatan hanya sekelompok kecil masyarakat yang memiliki pengetahuan tentang tanaman pasak bumi dengan skill atau keahlian khusus dalam teknik pemungutan. Hal ini karena sifat akar tunjang pasak bumi membutuhkan keahlian khusus dalam melakukan pemungutan. Atribut komunitas pengumpul dan tengkulak adalah sebagai pedagang perantara yang menghubungkan pemungut dengan pasar. Secara kemampuan akses informasi dan permodalan, pengumpul, tengkulak dan pedagang mempunyai akses informasi dan modal lebih baik daripada pemungut. Secara umum atribut komunitas pemungut, pengumpul, tengkulak dan pedagang mempunyai homogenitas dalam pemanfaatan pasak bumi yang terwujud melalui interaksi dan proses kerjasama dengan membentuk pola ketergantungan tata niaga pasak bumi. Hess dan Ostrom (2007) menyatakan bahwa komunitas yang homogen adalah apabila komunitas, baik penyedia maupun pengambil keputusan bersatu dalam pemanfaatan sumber daya bersama yang terwujud melalui proses kerjasama dan koordinasi antar pihak-pihak tersebut dalam menentukan sumber daya bersama.

\section{Sistem Pengusahaan Pasak Bumi}

Sistem pengusahaan pasak bumi masih mengandalkan dari alam dengan cara mencabut akar (Nuryamin, 2000; Julisasi, 1992; Ginting 2010). Sistem pemungutan pasak bumi yang ekstensif merupakan ancaman bagi keberadaan spesies tersebut karena hingga saat ini masyarakat belum mampu melakukan budidaya dan proses pertumbuhan pasak bumi yang lambat. Hal ini sesuai dengan hasil penelitian Hussein et al. (2005) yang menyatakan bahwa selama ini perbanyakan tanaman pasak bumi hanya mengandalkan biji di alam. Padahal sebagai tanaman yang memiliki tipe benih rekalsitran, persentase kecambahnya cenderung rendah dan memerlukan waktu yang cukup lama akibat embrio zigotik yang belum matang pada saat pemencaran. Selain itu, perilaku berbunga yang tidak tentu dan pertumbuhannya yang lambat mengakibatkan tanaman ini semakin jarang ditemui. Masyarakat melakukan pemungutan pada pasak bumi yang mempunyai diameter batang berkisar $15-20 \mathrm{~cm}$ dengan tujuan untuk tetap menjaga populasi pasak bumi di alam dan diameter akarnya bisa dibuat untuk cawan atau cangkir.

Masyarakat sekitar gunung Ambawang mencari pasak bumi berdasarkan pesanan dari pengumpul dan pengumpul mendapat pesanan dari tengkulak. Berdasarkan hasil penelitian, frekuensi transaksi antara tengkulak dengan pedagang terjadi kurang lebih 1-2 bulan sekali. Dalam mencari pasak bumi biasanya dilakukan secara berkelompok, yaitu antara 2-3 orang. Anggota kelompok biasanya masih mempunyai hubungan keluarga dan yang memiliki pengetahuan dan skill teknik pemungutan pasak bumi. Lokasi pencarian pasak bumi berada dekat dengan kampung tempat tinggal yang dapat ditempuh dengan berjalan kaki kurang lebih 1 jam. Peralatan yang digunakan untuk mencabut akar pasak bumi menggunakan rantai chainsaw atau cengblok, palu dan parang. Keterbatasan modal mengkondisikan pemungut untuk meminjam kepada tengkulak. Modal berupa peralatan untuk pemungutan dan uang untuk operasional di lapang. Konsekuensi dari ikatan modal ini, pemungut harus menjual hasil pasak bumi kepada pedagang yang memberi modal. Hubungan ketergantungan ini menciptakan kelembagaan patron klien antara pemungut, pengumpul dan tengkulak. Sedangkan di tingkat tengkulak, ada yang terikat modal dengan pedagang di Pontianak dan ada yang tidak terikat modal dengan pedagang di Pontianak. 


\section{Hubungan Ketergantungan Patron Klien}

Karakteristik alami pengusahaan pasak bumi, atribut komunitas masyarakat sekitar gunung Ambawang dan kondisi fisik alam telah melahirkan hubungan saling ketergantungan antara pemungut pasak bumi dengan pedagang. Pedagang membutuhkan pemungut pasak bumi sebagai anak buah untuk melakukan ekspedisi ke hutan. Sedangkan pemungut membutuhkan pedagang untuk memasarkan pasak bumi. Adanya hubungan ketergantungan ini selanjutnya melahirkan kelembagaan tradisional tataniaga pasak bumi yang bersifat informal, tidak ada administrasi dan aturan-aturan atau kesepakatan tertulis. Adanya pihak yang berada dalam posisi lebih baik dibanding pihak lain, baik dalam segi ekonomi ataupun penguasaan informasi melahirkan bentuk kelembagaan tataniaga pasak bumi dengan sistem patron klien (Scott, 1993).

Akibat adanya informasi yang tidak seimbang antara patron dan klien ini akan memunculkan masalah salah pilih (adverse selection) dan moral hazard (Lane, 2003). Hubungan patron klien mencerminkan posisi tawar menawar relatif dari kedua belah pihak. Anak buah sebagai klien sering berada dalam posisi tawar yang lemah. Berdasarkan hasil wawancara, dalam penetapan kualitas pasak bumi lebih didasarkan sepihak dari patron dengan penilaian secara visual dan kurang berdasarkan pada kesepakatan kedua belah pihak. Kondisi ini cenderung membuat individu berperilaku oportunistik yang menyebabkan munculnya persoalan bencana moral (moral hazard) seperti muncul ketidak loyalitasan pemungut sebagai anak buah yang menjual hasil pasak buminya kepada tengkulak lain.

Tingginya biaya untuk monitoring juga menyebabkan lemahnya pengawasan patron kepada klien yang menimbulkan perilaku klien tidak loyal dengan bekerja menjadi anak buah tengkulak yang lain yang memberikan harga lebih tinggi. Lemahnya monitoring dan posisi tawar yang rendah dalam penentuan harga menimbulkan perilaku klien ketika pasak bumi akan diambil oleh tengkulak pasak bumi sengaja dibasahi terlebih dahulu agar timbangan menjadi berat karena harga ditentukan dari berat timbangan.

\section{E. Pola Tata niaga Pasak Bumi dan Biaya Transaksi}

Berdasarkan pengamatan pola tata niaga pasak bumi yang terbentuk ada dua, yaitu pola tata niaga yang terbentuk dalam kelembagaan patron klien dan pola tata niaga pada kelembagaan tidak terikat modal. Observasi di lapangan menunjukkan peran tengkulak dalam tata niaga pasak bumi ini baik dalam kelembagaan patron klien maupun kelembagaan yang tidak terikat modal sama-sama berperan sebagai patron di tingkat desa. Terdapat integrasi vertikal antara pelaku yang terikat modal dengan pedagang yang memberi pinjaman modal kerja. Implikasi dari hubungan ini, pelaku yang terikat modal tidak dapat menjual hasil pasak buminya kepada pedagang lain sebagaimana anak buah yang terikat dengan patronnya. Sedangkan pelaku yang tidak terikat modal bebas menjual hasil pasak bumi yang dimiliki kepada sembarang pembeli. Meskipun demikian, berdasarkan wawancara ada kecenderungan pelaku menjual pasak buminya kepada pedagang yang sudah dikenalnya karena sudah saling percaya dalam menentukan harga. Pertimbangannya menurut mereka apabila menjual kepada pedagang yang baru dikenal biasanya sulit untuk mencapai kesesuaian kualitas dan harga. Namun demikian dari hasil wawancara dan observasi, diferensiasi harga hanya terjadi di tingkat tengkulak dengan selisih harga sebesar Rp. 1000/ kg. Terdapat dua tengkulak yang beroperasi di Kabupaten Kubu Raya, dan diferensiasi harga ini merupakan perilaku persaingan antara kedua tengkulak tersebut yang memicu terjadinya perilaku moral hazard seperti muncul ketidak loyalitasan pemungut sebagai anak buah yang menjual hasil pasak buminya kepada tengkulak lain.

Usaha tata niaga pasak bumi dihadapkan pada faktor risiko berupa ketidakpastian produksi dan tingkat kejujuran (loyalitas). Risiko yang dihadapi pemungut pasak bumi, dengan modal kerja yang dibutuhkan untuk mencari pasak bumi, relatif lebih kecil risikonya dengan meminjam modal atau menjadi anak buah seorang pengumpul pasak bumi. Sedangkan kerugiannya dengan terikat modal setiap transaksi berada dalam posisi tawar yang rendah. Di sisi lain, tengkulak sebagai pedagang perantara kelembagaan tata niaga di tingkat desa dengan di tingkat kota juga menanggung risiko dengan menanggung biaya transaksi yang lebih tinggi. Biaya tersebut meliputi biaya untuk koordinasi dengan pengumpul, biaya komunikasi, biaya pengemasan dan biaya transportasi ke kota yang ditempuh melalui jalan darat dan air. Untuk tengkulak yang tidak terikat modal biaya yang ditanggung lagi adalah biaya mencari informasi harga. 


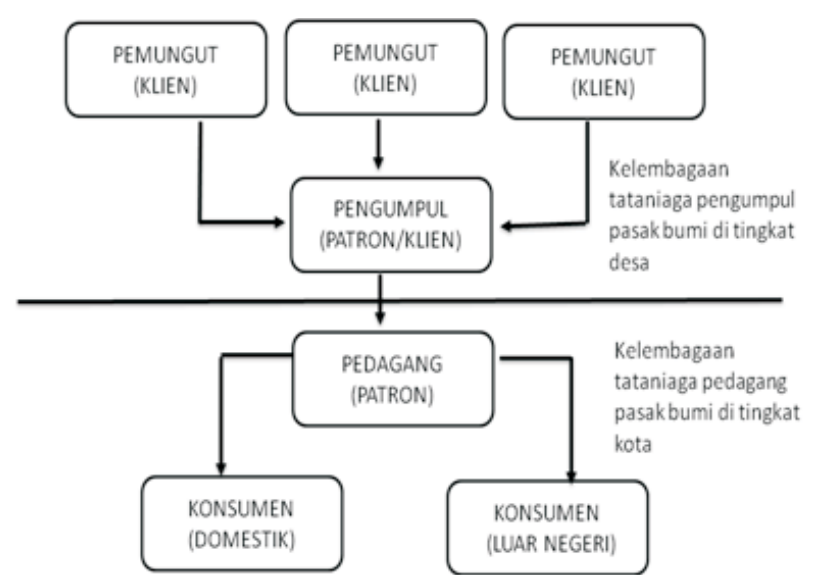

Gambar2. Pola tata niaga pasak bumi pada kelembagaan patron klien.

Figure 2. Pattern of pasak bumi distribution based on patron client relation.

Berdasarkan wawancara dari pedagang pasak bumi di Pontianak, risiko dan biaya transaksi yang ditanggung pedagang di kota Pontianak adalah tidak teraturnya suplai pasak bumi akibat karakteristik alam dan mahalnya biaya pengangkutan yang berpengaruh terhadap transaksi dan pengawasan terhadap anak buah. Selain itu biaya yang dikeluarkan adalah biaya untuk pengolahan dan pengemasan untuk diversifikasi produk dari pasak bumi berupa cawan atau gelas pasak bumi, kemasan serut cacahan pasak bumi, ramuan pasak bumi, dan potongan kecil-kecil pasak bumi.

\section{F. Struktur Tataniaga Pasak Bumi}

Analisis struktur pasar berguna untuk memahami karakteristik pasar pasak bumi yang selanjutnya akan mempengaruhi perilaku tata niaga. Dari sudut kelembagaan, struktur pasar terdiri dari semua aturan formal dan atau aturan yang mengkoordinasi transaksi di pasar. Setiap pelaku pasar (pedagang) mempunyai aturan-aturan main yang diikuti (Duc, 2002). Analisis struktur dilakukan pada pada setiap tahap tataniaga, yaitu tingkat desa dan kota. Pelaku tataniaga di tingkat desa adalah pemungut, pengumpul dan tengkulak. Berdasarkan perbandingan jumlah pemungut enam orang, pengumpul satu orang dan tengkulak dua orang. Struktur tata niaga pasak bumi di tingkat desa antara pemungut dan pengumpul merupakan struktur monopsoni dimana hanya terdapat satu pengumpul

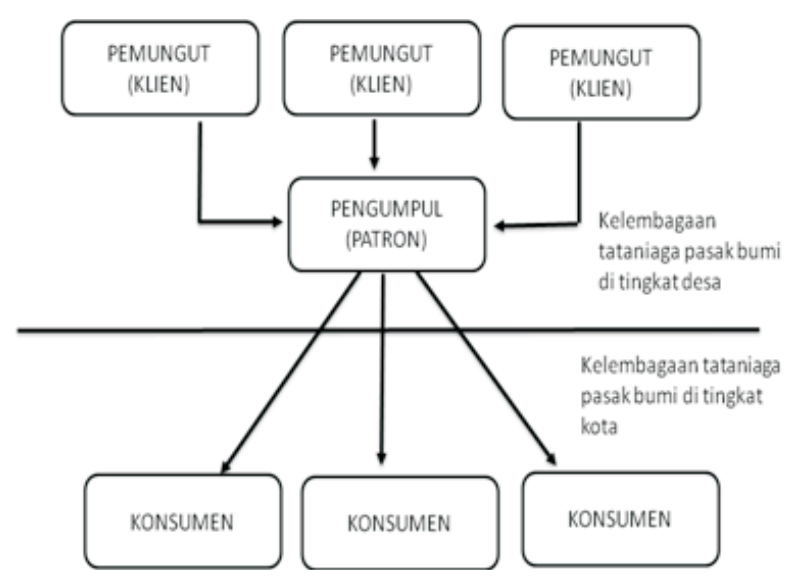

Gambar3. Pola tata niaga pasak bumi pada kelembagaan tidak terikat modal.

Figure 3. Pattern of pasak bumi distribution with no capital dependence.

yang menguasai pasokan pasak bumi. Sedangkan struktur pasar antara pengumpul dan tengkulak merupakan pasar oligopsoni dimana terdapat dua tengkulak yang menguasai pasokan pasak bumi. Hal ini sesuai dengan ciri-ciri pasar oligopsoni, yaitu terdapat dua tengkulak yang menerima pasokan atau menjadi pembeli, barang yang dijual berupa bahan mentah, dan pembeli bukan konsumen tetapi pedagang. Sedangkan struktur pasar di tingkat kota merupakan struktur oligopoli dimana hanya ada dua tengkulak yang secara kontinu menjual pasak bumi di kota Pontianak dengan jumlah pembeli 20 pedagang sehingga posisi tengkulak sebagai price maker. Terbentuknya pasar oligopoli ini didorong oleh adanya hambatan (barriers) untuk masuk pasar bagi pemain atau produsen baru (Dahl dan Hammod, 1977). Berdasarkan hasil analisis, hambatan untuk masuk pasar tata niaga pasak bumi yang dihadapi oleh pemain baru ini, antara lain disebabkan oleh:

a. Ada kecenderungan tengkulak sengaja menutup akses informasi tentang alamat, telepon, juga daerah pemungutan. Hal ini selain terkait sifat pasak bumi sebagai tanaman langka yang sekarang mulai susah dicari, juga menjaga daerah kekuasaan wilayah pemungutan dari pesaing

b. Tingkat kerumitan dalam pemungutan

c. Keterbatasan pemasok/pemungut 


\section{G. Kinerja Lembaga Tataniaga Pasak Bumi}

Kinerja kelembagaan tataniaga menggambarkan tingkat profitabilitas dan efisiensi dari suatu sistem pasar. Distribusi marjin pemasaran antar pelaku dapat digunakan sebagai pendekatan yang menentukan efisien tidaknya kelembagaan sesuai dengan biaya, risiko dan pengorbanan yang sudah dikeluarkan. Perhitungan marjin kotor diperoleh dengan menghitung selisih antara harga dibeli pengumpul dari pemungut dengan harga jual pada pemasaran berikutnya. Besarnya margin yang diperoleh tiap pelaku pemasaran tidak merata untuk tiap tingkat pemasaran. Berdasarkan hasil analisis dari wawancara dengan para pelaku mulai dari pemungut sampai dengan pedagang kota (provinsi) yang terikat dalam jaringan patron klien, bervariasinya margin ini sebagai dampak tidak adanya standar kualitas yang sama antar pedagang dan kurang sempurna informasi pasar yang berkaitan dengan perkembangan harga. Sebaran margin tata niaga pada setiap tingkatan lembaga tata niaga pasak bumi disajikan pada Tabel 2 dan rekapitulasi sebaran marjin disajikan pada Tabel 3 .

Tabel 2. Sebaran margin tata niaga pada setiap tingkatan lembaga tata niaga pasak bumi

Table 2. Margin distribution at every level of institution in trading chain of Pasak Bumi

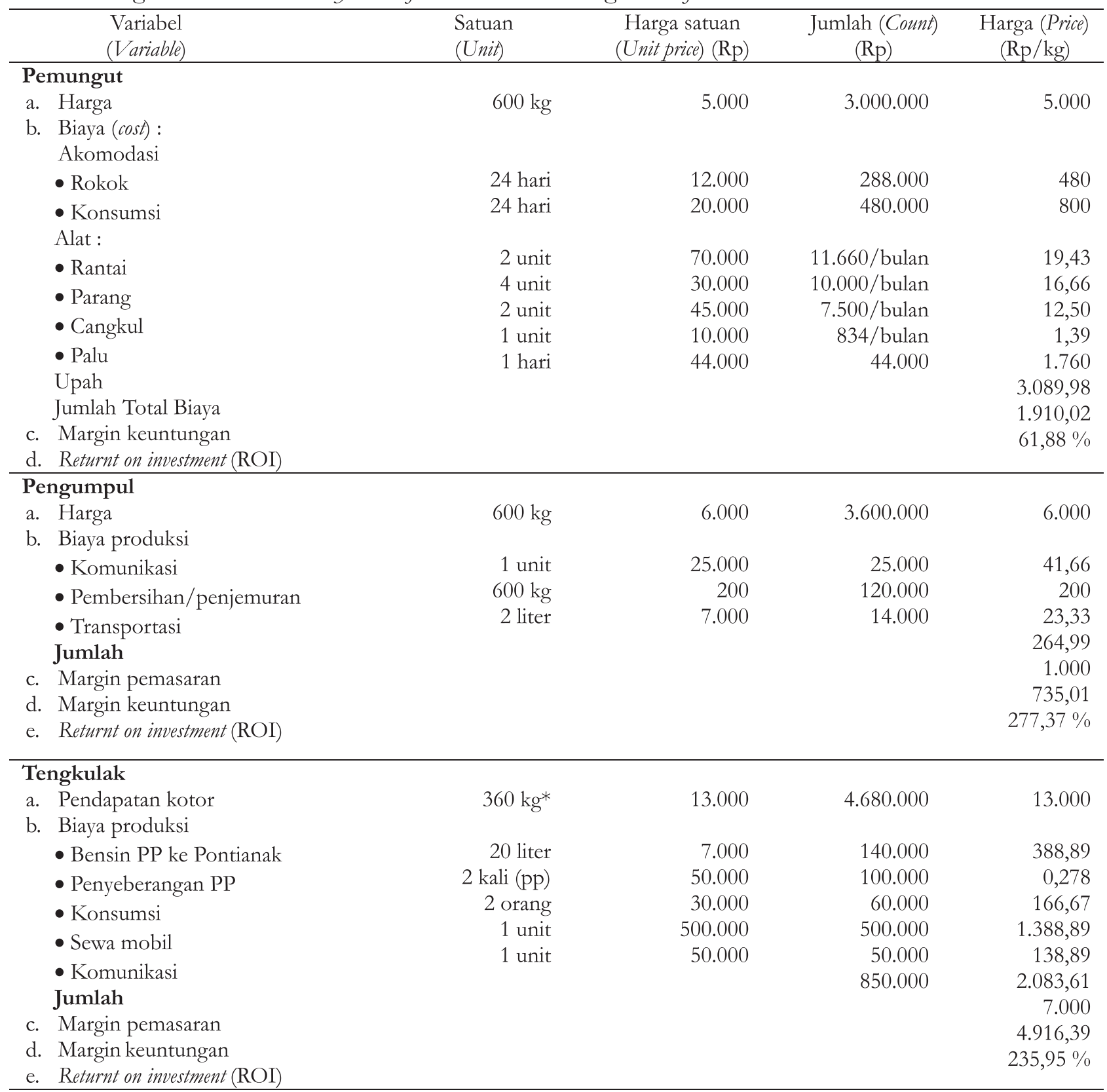


Tabel 2. Lanjutan

Table 2. Continued

\begin{tabular}{|c|c|c|c|c|}
\hline $\begin{array}{c}\text { Variabel } \\
\text { (Variable) }\end{array}$ & $\begin{array}{c}\text { Satuan } \\
\text { (Unit) }\end{array}$ & $\begin{array}{c}\text { Harga satuan } \\
\text { (Unit price) } \\
\text { (Rp) }\end{array}$ & $\begin{array}{c}\text { Jumlah } \\
\text { (Count) } \\
\text { (Rp) }\end{array}$ & $\begin{array}{c}\text { Harga } \\
(\text { Price }) \\
(\mathrm{Rp} / \mathrm{kg})\end{array}$ \\
\hline \multicolumn{5}{|l|}{ Pedagang } \\
\hline a. Pendapatan kotor & $200 \mathrm{btg} * *$ & 35.000 & 7.000 .000 & 35.000 \\
\hline \multicolumn{5}{|l|}{ b. Biaya produksi } \\
\hline Sewa kios & 1 unit/bulan & 1.250 .000 & 1.250 .000 & 6.250 \\
\hline Upah pegawai & 1 Orang & 400.000 & 400.000 & 2.000 \\
\hline Diversifikasi produk & 20 pax & 500 & 10.000 & $\begin{array}{r}50 \\
8\end{array}$ \\
\hline Jumlah & & & & 8.300 \\
\hline c. Margin pemasaran) & & & & 22.000 \\
\hline d. Margin keuntungan & & & & 13.700 \\
\hline e. Returnt on investment & & & & $165 \%$ \\
\hline
\end{tabular}

Keterangan (Remarks): * Dalam satu bulan terjadi penyusutan berat akar sebesar $40 \%$

** 1 batang beratnya $\pm 3 \mathrm{~kg}$, jadi volume akar seberat $360 \mathrm{~kg}$ sama dengan 120 batang akar

Tabel 3. Rekapitulasi sebaran marjin tata niaga pada setiap tingkatan lembaga tata niaga pasak bumi Table 3. Recapitulation of margin distribution at every level of institution in trading chain of Pasak Bumi

\begin{tabular}{llrrrr}
\hline & $\begin{array}{c}\text { Variabel } \\
(\text { Variable })\end{array}$ & $\begin{array}{c}\text { Pemungut } \\
(\text { Picker }) \\
(\mathrm{Rp} / \mathrm{kg})\end{array}$ & $\begin{array}{c}\text { Pengumpul } \\
(\text { Collector }) \\
(\mathrm{Rp} / \mathrm{kg})\end{array}$ & $\begin{array}{r}\text { Tengkulak } \\
(\text { Middle man }) \\
(\mathrm{Rp} / \mathrm{kg})\end{array}$ & $\begin{array}{c}\text { Pedagang } \\
(\text { Trader }) \\
(\mathrm{Rp} / \mathrm{kg})\end{array}$ \\
\hline a. Harga & 5.000 & 6.000 & 13.000 & 35.000 \\
b. Biaya & $3.089,98$ & 265 & $2.083,61$ & 8.300 \\
c. & Margin pemasaran & 0 & 1.000 & 7.000 & 22.000 \\
d. Margin keuntungan & $1.910,02$ & 735 & $4.916,39$ & 13.700 \\
e. & Returnt on investment $(\mathrm{ROI})$ & $61,88 \%$ & $277,37 \%$ & $235,95 \%$ & $165 \%$ \\
\hline
\end{tabular}

Berdasarkan hasil analisis terlihat bahwa lembaga tataniaga yang memperoleh margin keuntungan terbesar adalah pedagang di kota sebesar Rp 13.700/kg. Penetapan harga pasak bumi di tingkat pedagang tidak lagi berdasarkan pada nilai berat $(\mathrm{kg})$ seperti pada penetapan harga di rantai tata niaga sebelumnya, namun berdasarkan harga jual per batang. Hal ini karena sifat berat kayu pasak bumi yang cepat menyusut sehingga pasak bumi di jual dalam satuan unit batang. Manipulasi berat menjadi batang ini memberikan nilai marjin tata niaga dan margin keuntungan yang tinggi.

Pengumpul merupakan pihak yang memperoleh keuntungan paling kecil, hal ini karena pengumpul sebenarnya pemungut yang bertindak sebagai koordinator yang diberi tugas oleh tengkulak untuk memimpin ekspedisi mencari pasak bumi. Namun demikian dilihat dari nilai return on investment (ROI), yaitu nilai yang menunjukkan efisiensi dari modal yang diinvestasikan, pengumpul mempunyai nilai ROI tertinggi yaitu sebesar 277,37\%. Nilai ini menunjukkan bahwa setiap rupiah yang diinvestasikan untuk usaha pasak bumi akan memberikan keuntungan sebesar Rp 277,37. Hal ini sesuai dengan pernyataan Wild et al. (2005) bahwa semakin besar nilai ROI maka semakin besar pula tingkat pengembalian investasi. Hal ini disebabkan oleh dua hal, pertama, biaya yang dikeluarkan oleh pengumpul paling kecil karena hanya bertindak sebagai koordinator pemungut sehingga nilai risikonya juga paling kecil, dan kedua karena sumber daya pasak bumi ditambang langsung dari hutan, bukan dari hasil budidaya. Dari aspek kelestarian kondisi ini mengancam keberadaan pasak bumi di alam karena bisa memacu pemungut untuk memungut pasak bumi sebesar-besarnya untuk meningkatkan keuntungan. 


\section{KESIMPULAN DAN SARAN}

\section{A. Kesimpulan}

Karakteristik alami pengusahaan pasak bumi, atribut komunitas masyarakat sekitar gunung Ambawang dan kondisi fisik alam serta pengelolaan state property yang tidak efektif telah melahirkan interaksi saling ketergantungan komunitas tata niaga pasak bumi. Adanya pihak yang berada dalam posisi lebih baik dibanding pihak lain, baik dalam segi ekonomi ataupun penguasaan informasi melahirkan bentuk kelembagaan tata niaga pasak bumi dengan sistem patron klien. Berdasarkan hasil analisis kinerja, tata niaga pasak bumi tidak efisien karena margin share yang diperoleh tiap pelaku pemasaran tidak merata untuk tiap tingkat pemasaran. Pengumpul memperoleh keuntungan yang paling kecil, namun memiliki nilai ROI paling besar. Hal ini disebabkan oleh dua hal, pertama, biaya yang dikeluarkan oleh pengumpul paling kecil karena hanya bertindak sebagai koordinator pemungut sehingga nilai resikonya juga paling kecil, dan ke dua karena sumber daya pasak bumi ditambang langsung dari hutan. Artinya, dari aspek kelestarian kondisi ini mengancam keberadaan pasak bumi di alam karena dapat memacu pemungut untuk memungut pasak bumi sebesarbesarnya untuk meningkatkan keuntungan.

\section{B. Saran}

Dalam upaya mengantisipasi kelangkaan pasak bumi, perlu dilakukan penelitian potensi dan persebaran pasak bumi secara menyeluruh sehingga dapat dihitung kuota pemungutan akar pasak bumi (kg/ha) secara lestari. Perlunya keseimbangan informasi antar pelaku tata niaga. Perlu adanya usaha pengembangan teknik budidaya pasak bumi sehingga pemungutan secara langsung di alam dapat dikurangi.

\section{DAFTAR PUSTAKA}

Ang, H.H., Lee, K.L. \& Kiyoshi M. (2004). Sexual arousal in sexually sluggish old male rats after oral administration of Eurycoma longifolia Jack. J Basic Clin Physiol Pharmacol 15, 303-309.
Ang, H.H., Ngai, T.H. \& Tan, T.H. (2003). Effects of Eurycoma longifolia Jack on sexual qualities in middle aged male rats. Phytomedicine 10, 590-593.

Bromley, D.W. (1992). The commons, property, and commons property regime. In: Bromley, D.W et al. (eds). Making the Commons World. San Francisco: ICS Press.

Chan, K.L., Choo, Cy. \& Abdullah, N.R. (2005). Semisynthetic 15-O-acyl- and 1,15-di-Oacyleurycomanones from Eurycoma longifolia as potential antimalarials. Planta Med 71 (10), 967-969.

Dahl, D.C, \& J.W. Hammod. (1977). Market andprice analysis. The agricultural industries. New York: Mc-Graw Hill Company.

Effendy, N.M., Norazlina, M., Norliza, M., Isa, N.M., \& Ahmad, N.S. (2012). Eurycoma longifolia :Medicinal plant in the prevention and treatment of male osteoporosis due to androgen deficiency. Hindawi Publishing Corporation Evidence-Based Complementary and Alternative Medicine, Volume 2012, Article ID 125761, 9 pages.

Farouk, A.E., Benafri, A. (2007). Antibacterial activity of Eurycoma longifolia Jack. A Malaysian medicinal plant. Saudi Med J. 28, 1422-1424.

Farooquee, N.A., Majila, B.S, \& Kala, C.P. (2004). Indegenous knowledge systems and sustainable management of natural resources in a high altitude society in Kumaun Himalaya, India. Journal of Human Ecology 16, 33-42.

Ghimire, S.K., McKey, D., \& AerumeeruddyThomas, Y. (2005). Heterrogeneity in etnoecological knowledge and management of medicinal plants in the Himalayas of Nepal : Implication for conservation. Ecology and Society 9, 36.

Ginting, B.R, \& Aminata. (2010). Kajian ekologi pasak bumi (Eurycoma longifolia Jack) dan pemanfaatan oleh masyarakat di sekitar Hutan Bukit Lawang (tesis). Pogram Studi Magister 
Ilmu Biologi Fakultas Matematika dan Ilmu Pengetahuan Alam, Universitas Sumatera Utara, Medan.

Heyne, K. (1987). Tumbuban obat berguna (Jilid I-III). Bogor: Badan Litbang Kehutanan.

Hussein, S., Ibrahim, R., Kiong, A.L.P., Fadzilah, N.M., \& Daud, S.K. (2005). Multiple shoot formation of important tropical mediclinal plant, Eurycoma longifolia Jack. J. Biotechnol 22, 349-351.

Julisasi, T.H. (1992). Kajian ekologis pasak bumi (Eurycoma longifolia Jack) di areal HPH PT. Siak Raya Timber Riau. (Skripsi). Jurusan Konservasi Sumberdaya Hutan Fakultas Kehutanan, Institut Pertanian Bogor, Bogor.

Kala, C.P., Farooquee, N.A., \& Dhar, U. (2004). Prioritization of medicinal plants on the basis of avalaible knowledge, existing practices and use value status in Uttaranchal, India. Biodiversity and Conservation 13, 453-469.

Kartodiharjo, H. (1998). Peningkatan kinerja pengelolaan butan alam produksi melalui kebijaksanaan penataan institusi. Bogor: Program Pascasarjana, Institut Pertanian Bogor.

Kuo, P.C., Shi, L.S., \& Damu, A.G. (2003). Cytotoxic and antimalarial beta-carboline alkaloids from the roots of Eurycoma longifolia. J NatProd. 66, 1324-7.

Kuo, P.C., Damu, A.G., Lee, K.H., \& Wu, T.S. (2004). Cytotoxic and antimalarial constituents from the roots of Eurycoma longifolia. Bioorg Med Chem 12, 537-44.

Lane, Jan-Erik. (2003). Relevance of the principalagent framework to public policy and implementation. (Working paper) University of Geneva and National University of Singapore.

Nurhanan, M.Y., Azimahtol, H.L.P., Mohd, I.A., \& Shukri, M.A. (2005). Cytotoxic effects of the root extracts of Eurycoma Longifolia Jack. PhytoterRes. 19 (11), 994-6.

Nuryamin, A. (2000). Studipotensi tumbullan obat akar kuning (Arcangelisia flava (L.) Merr), pasak bumi (Eurycoma longifolia Jack), seluang belum (Luvunga eleutherandra Dalv) dan gingseng kalimantan
(Psycotria valetonii Hochr) di areal kerja HPN PT. Manimbun Djaja (Djajanti Group) Kalimantan Tengah. Bogor: Institut Pertanian Bogor.

Ostrom, E. (2003). How types of goods and property rights jointly affect collective action. Journal of Theoretical Politics 15 (3):239270.

Ostrom, E. (2005). Doing institutional analysis: Digging deeper than markets and hierarchies. pp.819-848. In C. Ménard \& M. Shirley, (eds). Handbook of New Institutional Economics. Springer.

Ostrom E., \& Hess C. (2007). Private and common property rights. Retrieved from Workshop in Political Theory and Policy Analysis. Indiana University. Social Science Research Network. http://papers.ssrn.com. (15 Desember 2013).

Pakpahan, A. (1989). Kerangka analitik untuk penelitian sosial: perspektif ekonomi institusi. Dalam Prosiding Patanas: Evolusi kelembagaan pedesaan di tengah perkembangan teknologi pertanian. Bogor: Pusat Penelitian Agroekonomi.

Ribot, J.C., \& Peluso, N.L. (2003). A theory of access. Rural Sociology 68 (2), 153-181.

Rifai, M.A. (1992). Eurycoma longifolia Jack. (pp 128). In Rifai et al. (eds.), Tiga Pulub Tumbuban Langka Indonesia. Floribunda 2.

Scott, J.C. (1993). Perlawanan kaum tani. (Edisi Pertama). Jakarta: Yayasan Obor.

Suresh, S., Prithiviraj, E., \& Prakash, S. (2009). Dose and time-dependent effects of ethanolic extract of Mucuna pruriens Linn. seed on sexual behaviour of normal male rats. Journal of Ethnopharmacology 122, (3), 497-501.

Tee, T.T., Cheah, Y.H., \& Hawariah, L.P. (2007). A fraction from Eurycoma longifolia jack extract, induces apoptosis via a caspase-9independent manner in MCF-7 cells. AnticancerRes 27, 3425-30.

Wild, R.F., Halsey, Kr., \& Subramanyam, J.J. (2005). Analisis laporan kenangan. (Buku 2. Ed. 8.). (Yanivi, S.B., \& Harahap, S.N.) Penerjemah). Jakarta: Salemba Empat. 